\title{
Effect of Various Temperatures on Symptom Expression by Different Plant Species (Cucumber, Plantain, and Banana) Affected by Cucumber Mosaic Virus
}

\author{
Julio Bird, Josefina Sánchez, Marco A. Tió, and Lii-Jang Liu ${ }^{1}$
}

\section{INTRODUCTION}

Mosaic of plantains (Musa paradisiaca L.) and bananas (Musa sapientum L.) occurs frequently in the lowlands and the coastal plains of Puerto Rico. Incidence of the disease in such areas, however, has been noted to be extremely low during the summer and never too serious during winter months. At the height of the warm season, it is almost impossible sometimes, even in the highlands, to locate musaceous plants with acute symptoms of mosaic. Serious outbreaks of banana and plantain mosaic occur consistently every year, however, in the highlands during the cool winter months, at times under conditions which would seem to preclude the spread of the disease by aphid vectors. The low incidence of the disease observed in coastal areas appeared to have had been induced by high temperatures. It has been shown in certain aphid-transmitted plant viruses that temperature often modifies plant susceptibility to infection.

According to Welton et al. $(7)^{2}$ the number of plants infected with bean yellow mosaic virus via aphids decreased when plants were subjected to pre-inoculation temperatures in the $15^{\circ}$ to $33^{\circ} \mathrm{C}$. range. Afanasiev (1) reported in 1967 that Lambert cherry trees infected with mottle virus required exposure to cool temperatures during the dormancy period for expression of disease symptoms. It also has been shown that strains of plant viruses differ in their ability to multiply in plants kept at certain temperatures. Badami (2) provided evidence to indicate that the Spanish strain of cucumber mosaic virus failed to multiply and cause symptoms on tobacco plants kept at temperatures above $30^{\circ} \mathrm{C}$. Hitchborn (4) reported that some strains of cucumber mosaic virus multiplied at $37^{\circ} \mathrm{C}$. while other strains did not appear to multiply at the same temperature. Holmes (5) and Kassanis (6) proposed heat therapy for certain virus-infected plants.

The present study was undertaken to determine the relative effect of

${ }^{1}$ Phytopathologist and Director, Department of Phytopathology and Botany, Assistant Biologist, Phytophysiologist, and Phytopathologist, respectively, Agricultural Experiment Station, Mayagüez Campus, University of Puerto Rico, Río Piedras, P.R.

${ }^{2}$ Italic numbers in parentheses refer to Literature Cited, p. 77. 
different temperatures on symptom expression by plantain, banana and cucumber plants inoculated with local isolates of the cucumber mosaic virus.

\section{MATERIALS AND METHODS}

The present study was carried out in climate chambers provided with facilities to control accurately both temperature and humidity. Four glass-roofed chambers (10 feet by 13 feet) exposed to sunlight were used. The chamber temperatures were set at $65^{\circ}, 75^{\circ}, 85^{\circ}$ and $95^{\circ} \mathrm{F}$., respectively. Diurnal and nocturnal temperature fluctuations were minimal and never more than $2^{\circ} \mathrm{F}$. during the course of these experiments ( 3 months).

Relative humidity was maintained at 70 percent. Frequent readjustments had to be made at the $95^{\circ} \mathrm{F}$. chamber to keep a more or less constant relative humidity. This chamber also required artificial heating although the trials were carried out during the summer months. Plantain and banana test plants (four of each per treatment) had been inoculated previously with cucumber mosaic virus (CMV) via aphids, and were showing distinct symptoms of disease at the onset of the trials. The test plants were paired to healthy control plants and distributed in the various chambers because ample unused space existed within the chambers.

Similar experiments were initiated with cucumber seedlings. For these specific trials, flats each containing 50 healthy cucumber plants (cotyiedon stage) of the variety Black Diamond were set aside in a greenhouse and dusted with carborundum. The batch was divided into two equal lots. One lot was mechanically inoculated with a strain of CMV isolated from Musa sapientum and the other with the Commelina strain of the same virus. A suitable uninoculated control was included, consisting of 10 plants per flat. The environmental temperature at the time of inoculation was $75_{k}^{\circ} \mathrm{F}$. After rinsing the inoculated plants with water, each flat was moved to the corresponding chamber. The transfer was effected about 30 minutes after inoculation. The plantain, banana and cucumber plants were maintained at the various climatic chambers for a period of 3 months at which time final observations, were made.

\section{EXPERIMENTAL RESULTS}

\section{$95^{\circ}$ F. CHAMBER}

\section{Musaceous Species}

In general, about 3 weeks after the treatment was initiated, a tendency towards mitigation of symptoms could be observed on the new leaves of treated plants. About a week later two plantain plants developed heart rot (apical necrosis) and side shoots arose from their bases. These shoots at 
first bore mild symptoms of disease, but at the end of the trial one was symptomless (the uppermost leaves) and the other very mildly affected. The rest of the plants recovered slowly but steadily, and after $21 / 2$ months only a few lenticular spots, suggestive of primary symptoms, were evident on their topmost leaves. None of the banana plants became necrotic. At the end no signs of disease could be noted on the topmost leaves of the test

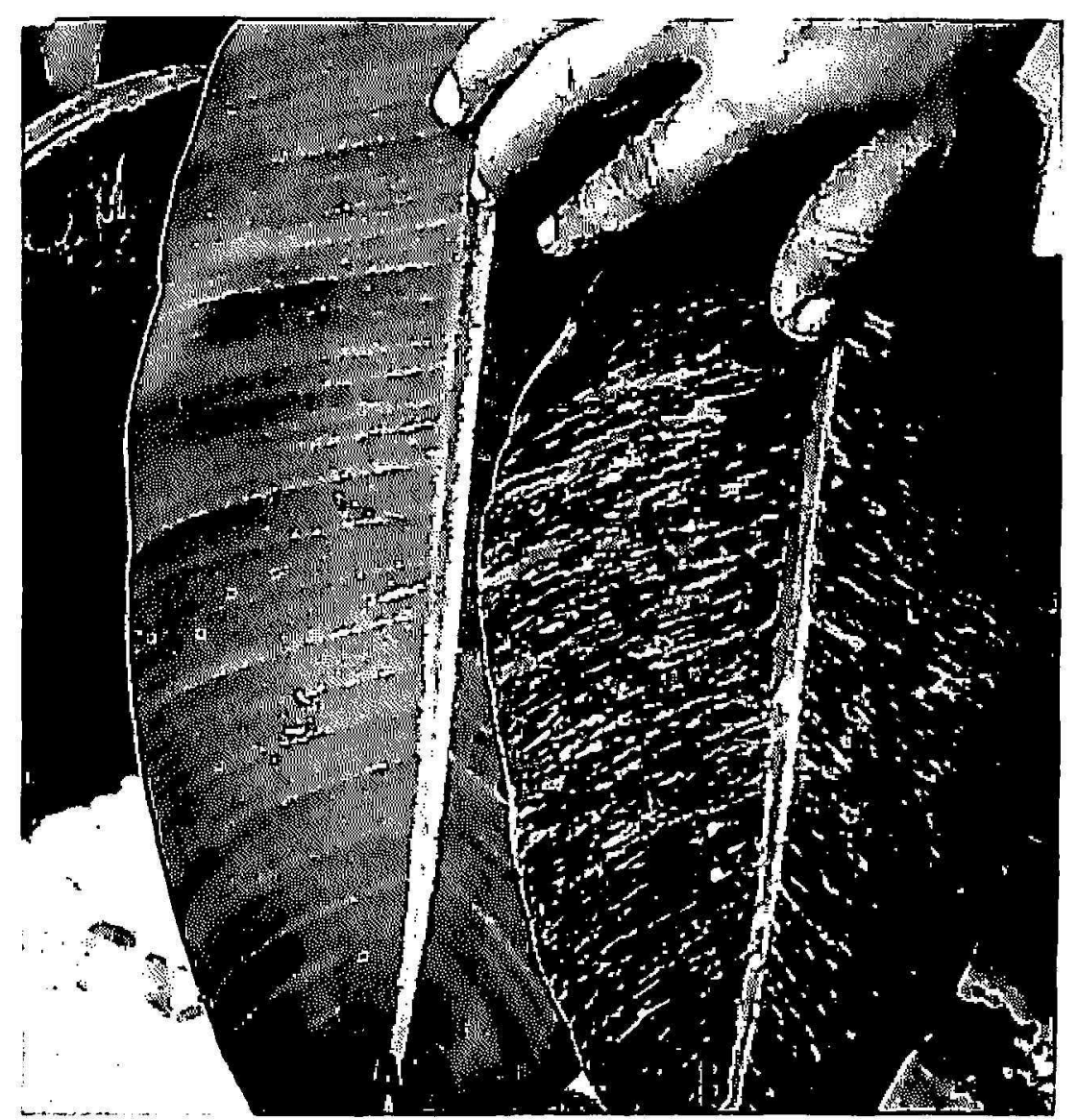

Fig. 1.-Effect of temperature on expression of symptoms by banana plants of the variety Montecristo: A, Mosaic-free leaf produced by virus affected plant kept at $95^{\circ} \mathrm{F}$. B, mottled leaf produced by virus affected plant kept at $65^{\circ} \mathrm{F}$.

plants (fig. 1). In a period of 50 days an average of four new leaves were produced by the musaceous test plants. This is of interest because their counterparts in the $85^{\circ}$ and $75^{\circ} \mathrm{F}$. chambers produced an average of three leaves while the ones at the $65^{\circ} \mathrm{F}$. chamber only produced two leaves during the same period.

\section{Cucumber Plants}

More than 90 percent of the seedlings developed symptoms of disease as a result of inoculation with the Musa strain of CMV. Similar results were obtained in the case of the Commelina strain of CMV. The Commelina 
strain which normally is lethal to cucumbers was not overly pernicious at this temperature, however, and at the end of the trials the plants were growing almost normally and exhibiting very mild symptoms of disease

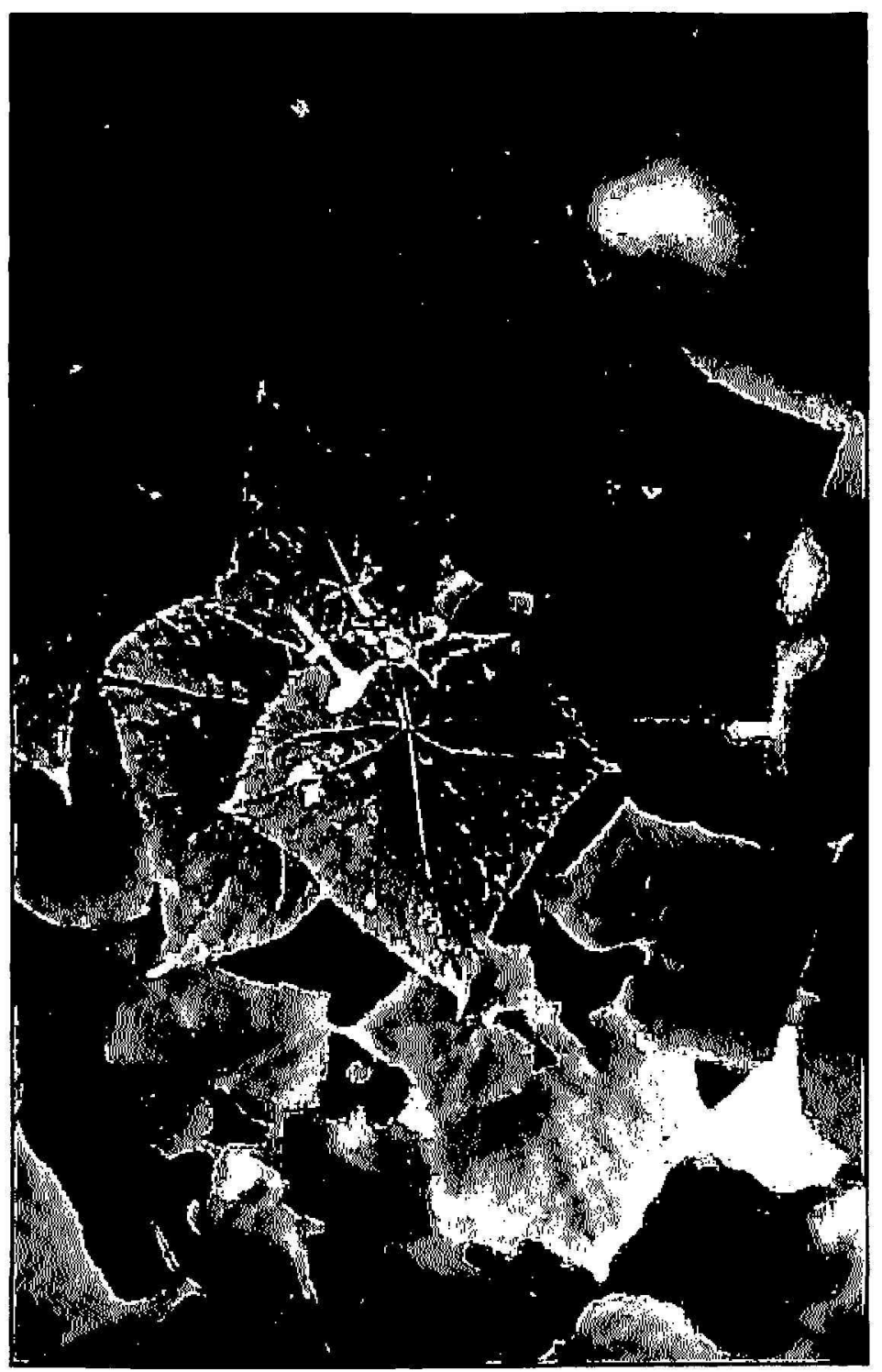

FIG. 2.-Mild symptoms of mosaic on a cucumber plant of the variety Black Diamond which was kept at the high temperature chamber $\left(95^{\circ} \mathrm{F}\right.$.). This plant was affected by the Commelina strain of the CMV which is normally lethal to cucumber at temperatures in the vicinity of $5^{\circ} \mathrm{F}$.

(fig. 2). When the trials were concluded symptoms were almost non-existent in the case of the plants inoculated with the Musa strain. It has to be noted at this point that the authors had never seen results such as those obtained in the case of the seedlings inoculated with the Commelina virus. Assuming this is to be the result of direct attenuation of the virus by the constantly high temperature, an experiment was conducted to verify this 
assumption. The three topmost opened leaves of the cucumber plants thus affected by the Commelina virus were ground and the resulting extract used to inoculate a new lot of cucumber seedlings (kept at the $75^{\circ} \mathrm{F}$. chamber). Fifty plants thus inoculated died within 10 days. This indicated that the virus had not lost its virulence and that its titer was high. In all probability the dramatic resistance of the cucumber seedlings to the Commelina virus is not due to the attenuation of the virus by a sustained high temperature.

\section{$85^{\circ}$ F. CHAMBER}

\section{Musaceous Species and Cucumber Plants}

Results similar to the foregoing, although not so dramatic, were observed in this temperature treatment (fig. 3). Close to 90 percent of the cucumber plants inoculated with the Commelina strain of the CMV became necrotic. A few resisted the Commelina strain and continued to grow although visibly affected and stunted.

\section{$75^{\circ}$ F. CHAMBER}

\section{Musaceous Species}

Severe symptoms of disease were evident on all the musaceous hosts (fig. 4). At the end of 1 month all the plantain plants had developed heart rot. None of the main shoots of these plants were superseded by lateral shoots, and even the corms succumbed to necrosis.

\section{Cucumber Plants}

As in the other treatments, more than 90 percent of the plants were successfully inoculated. Those inoculated with the Musa strain of CNIV developed well-defined mosaic symptoms although the plants also grew rather well. It seemed that at this temperature there was a good balance between growth and development of the host and perpetuation of the Musa strain. The Commelina virus was lethal to the inoculated cucumber seedlings at this temperature.

$$
65^{\circ} \text { F. CHAMBER }
$$

\section{Musaceous Species}

Banana plants developed mosaic symptoms after 4 weeks the like of which the writers previously had observed only in the highlands during the cool winter months. Absence of streaks and lenticular spots was complete. Instead, affected plants developed a well defined and vivid mottle. This mottling was extremely severe and involved the whole leaf area. On becom- 
ing infected in the field, plantain plants usually develop heart rot. This also occured at the higher temperatures in the present study. However, at the $65^{\circ} \mathrm{F}$. treatment the plantain plants entered the mosaic stage producing

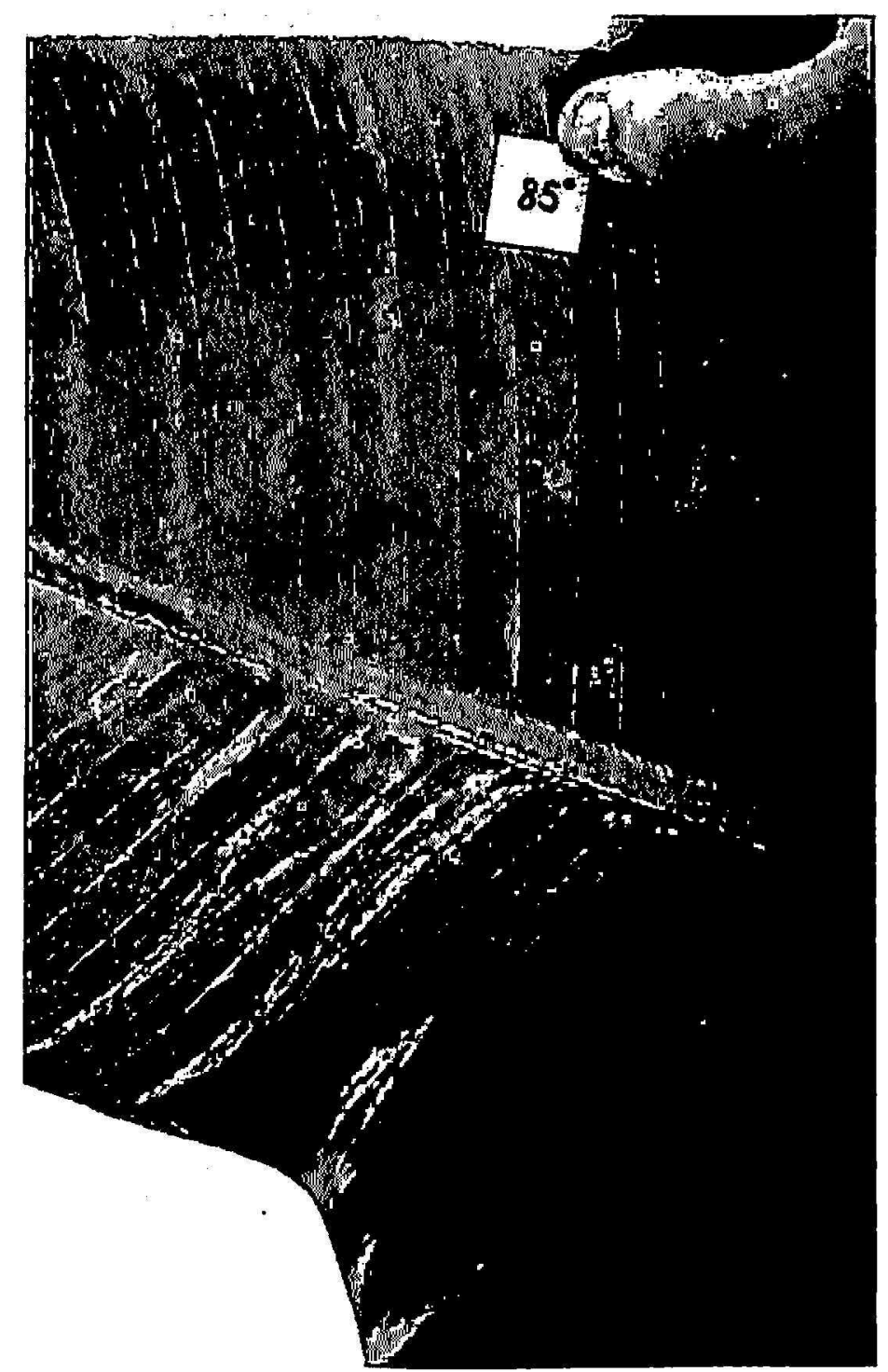

Fic. 3.-Mild symptoms on a banana leaf from a plant kept at $85^{\circ} \mathrm{F}$. for 3 months.

symptoms of the type generally found on banana plants in the field during the winter months.

\section{Cucumber Plants}

More than 90 percent of the plants inoculated with the Musa and the Commelina strains of the CMV developed symptoms of disease, i.e., severe mottling in the case of the ones inoculated with the Musa strain, and complete collapse and necrosis in the case of those inoculated with the Commelina strain. 


\section{DISCUSSION AND CONCLUSIONS}

The results of this study in general are in agreement with the findings of Badami (2) and Hitchborn (4) concerning the modifying effect of temperature on symptom expression by cucumber mosaic-affected plants. Probably many of the simultaneous outbreaks of banana and plantain

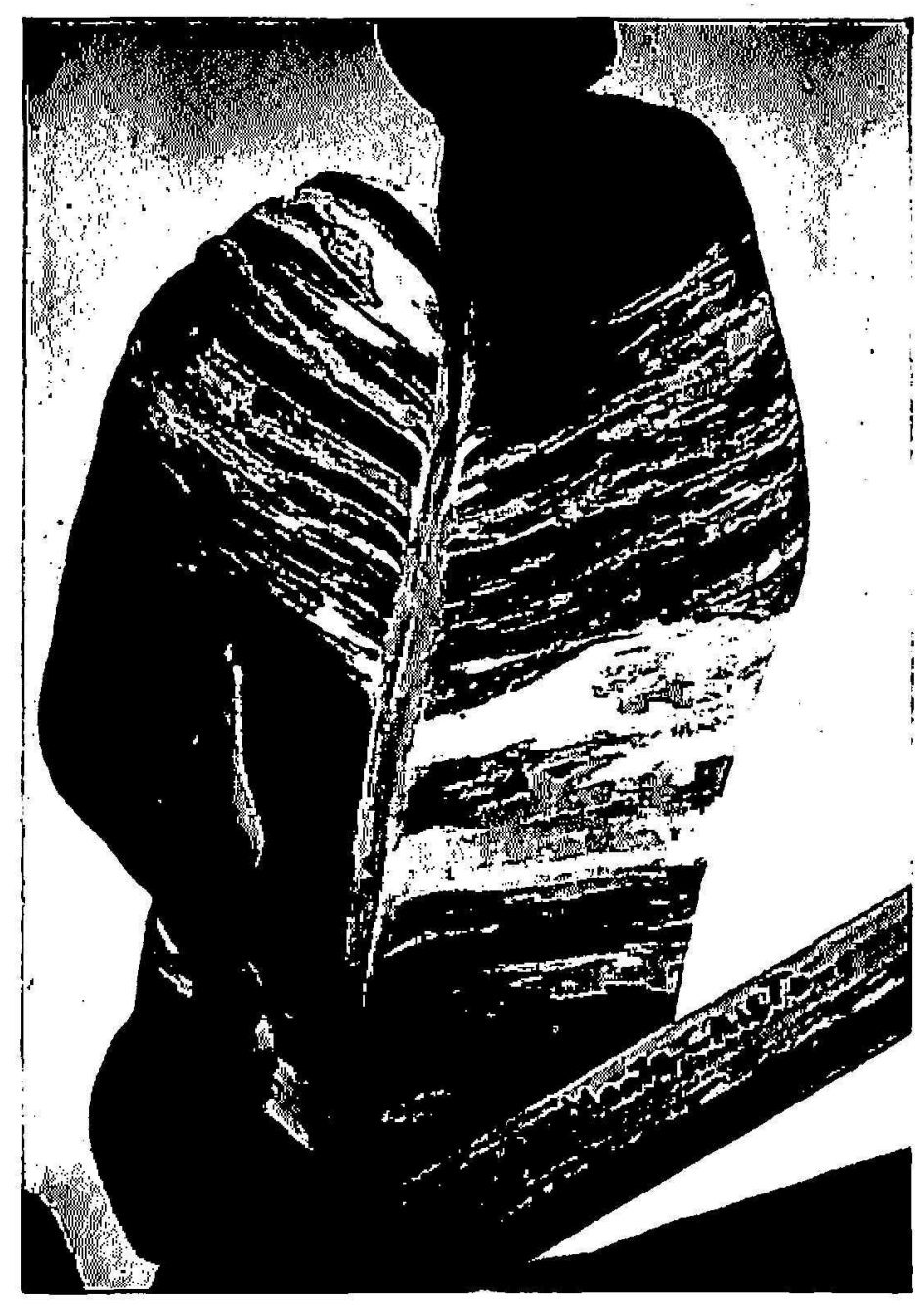

FrG. 4.- Severe mosaic symptoms on a leaf produced by an infected banana plant kept at $75^{\circ} \mathrm{F}$.

mosaic that occur during the winter season in the Puerto Rican highlands are due simply to the "activation" of latent cases of mosaic. Undoubtedly cool temperatures such as prevail in the winter months in our highlands (at the Barranquitas Station, for instance, where the average temperature for the month of January is $67.4^{\circ} \mathrm{F}$.) (8) exacerbate the symptoms of banana and plantain mosaic while high temperatures such as occur during the summer months in the coastal lowlands (at the Río Piedras Station, for instance, where the average temperature for the month of August is $80.8^{\circ} \mathrm{F}$.) (3) tend to conceal and mitigate the symptoms of the disease. 


\section{SUMMARY}

A study was made in climate chambers to determine the effect of various temperatures $\left(65^{\circ}, 75^{\circ}, 85^{\circ}\right.$, and $95^{\circ} \mathrm{F}$.) on symptom expression by cucumber, plantain and banana plants affected by cucumber mosaic virus. Mitigation of symptoms occurred when plantain, banana, and cucumber plants affected with cucumber mosaic virus were kept at $95^{\circ} \mathrm{F}$. At $85^{\circ} \mathrm{F}$., mitigation of symptoms was less dramatic. Some of the affected plants became necrotic and stunted. At $75^{\circ} \mathrm{F}$., severe symptoms of the disease were evident on test plants of the three species. At $65^{\circ} \mathrm{F}$., musaceous plants developed symptoms as severe as those observed in the highlands during the cool winter months. Cucumber plants developed severe mottling symptoms at this same temperature.

\section{RESUMEN}

Se hizo un estudio en cámaras climatizadas para determinar el efecto de varias temperaturas $\left(65^{\circ}, 75^{\circ}, 85^{\circ}\right.$ y $95^{\circ} \mathrm{F}$.) en el desarrollo de síntomas por plantas de pepinillo, banano y plátano afectadas por el mosaico común del pepinillo. Los síntomas prácticamente desaparecieron al someter las plantas a $95^{\circ} \mathrm{F}$. La reacción no fue tan dramática en el caso de las plantas sometidas a $85^{\circ} \mathrm{F}$. A esta temperatura el crecimiento de algunas plantas se detuvo; otras se tornaron necróticas. A los $75^{\circ} \mathrm{F}$. los síntomas se recrudecieron. Las musáceas desarrollaron síntomas tan severos en la cámera fría $\left(65^{\circ} \mathrm{F}\right.$.), como los que se observan en las montañas de Puerto Rico durante la época invernal. Otro tanto ocurrió en le caso de las plantas de pepinillo que se encontraban en la misma cámara.

Todo parece indirar que muchos de los casos de mosaico que aparecen en las musáceas durante el invierno en las alturas de Puerto Rico, se deben a la exacerbación de una virosis latente.

\section{LITERATURE CITED}

1. Afanasiev, M. M., Effect of temperature and length of incubation on symptom development of Lambert mottle of sweet cherries, Plant Dis. Reptr. 61(4): 269-70, 1967.

2. Badami, R. S., Some effects of changing temperature and of virus inhibitors on infection by cucumber mosaic virus, Ann. Appl. Biol. 47(1): 78-89, 1959.

3. Climatological Data, U. S. Department of Commerce, Puerto Rico and Virgin Islands Vol. 15 No. 13, Annual Summary 1969.

4. Hitchborn, J. H., The effect of temperature on infection with strains of cucumber mosaic virus, A.nn. Appl. Biol. 44(4): 590-8, 1956.

5. Holmes, F. O., Cures for virus diseases, Brooklyn Botanic Garden Record, Plants and Gardens 22(4): 28-31; 54, Winter 1966-67.

6. Kassanis, B., Heat-therapy of virus-infected plants, Ann. Appl. Biol. 41 (3): 470-4, 1954.

7. Welton, R. E., Swenson, K. G., and Sohi, S. S., Effect of temperature on plant susceptibility to infection with besn yellow mosaic virus by aphid transmission, Virology 28 : 504-10, 1964. 